\title{
História: que ensino é esse?
}

\section{Juliana Pirola da Conceição*}

É interessante quando abrimos um livro cujo título é uma pergunta, logo o folheamos na busca de respostas e deparamo-nos com uma enorme quantidade de autores, de perspectivas e, consequentemente, de respostas. A sensação é desconcertante, mas a surpresa é positiva, pois, assim, como são inúmeras as possibilidades de interpretação da história, também são inúmeras as perspectivas para 0 seu ensino. Essa é a proposta do livro: não definir a área, os seus sujeitos, os temas ou os objetos desde um único ponto de vista, mas a partir de relatos de memória, de práticas de ensino e de pesquisa busca-se refletir a respeito da importância do ensino de História na atualidade, em um momento delicado, quando órgãos públicos e entidades da sociedade civil contestam sua relevância no sistema escolar, especialmente no estado de São Paulo.

O livro é uma coletânea, organizada pelo professor e historiador Marcos Antonio da Silva, Livre Docente e Titular da área de Metodologia da História na FFLCH/ USP, que reúne 21 artigos de professores, pesquisadores, formadores e orientadores, de diferentes gerações e distintas regiões do país, comprometidos com a História e com o seu ensino, no ambiente escolar e também fora dele. Seu mérito está em procurar expor as várias respostas que o título enseja passados quase trinta anos da publicação de Repensando a história (1984), organizado pelo mesmo autor, como aponta Katia Maria Abud logo no prefácio. Alguns dos temas ali presentes são retomados sob novas perspectivas teóricas, e outros são incluídos, acompanhando as novas tendências da historiografia e as visões contemporâneas do ensino. Com isso, pode-se observar como caminharam as discussões e as propostas para a área em diferentes abordagens, seja no plano conceitual ou em relação aos conteúdos.

Enquanto no primeiro livro o enfoque estava na busca pela especificidade do saber histórico escolar, explorando as relações entre o historiador e o professor de História, livros didáticos, ideologia e poder - como no clássico artigo A vida e o cemitério dos vivos escrito pelo próprio autor, nesse segundo livro a abordagem é ampliada para a formação de professores de História. Nesse sentido, aborda o uso de novas fontes audiovisuais nas salas de aula (cinema, música e HQs), o uso de

\footnotetext{
Recebido: 05/05/2014 - Aprovado: 26/06/2014

http://dx.doi.org/10.5335/rep.v21i2.4311
}

Graduada em História pela Universidade Federal do Espírito Santo (UFES). Mestre em Educação pela Universidade Federal de Santa Catarina (UFSC). Doutoranda do Programa de Pós-Graduação em Educação da Unicamp, com bolsa Fapesp e integra o Grupo Memória, História e Educação. E-mail: jupirola@yahoo.com.br. 
drogas como objeto de conhecimento e como elemento da cultura global, o papel da performance na dinâmica da sala de aula e na construção do conhecimento histórico, o ensino de História na educação superior (abrangendo os cursos de Turismo e Hotelaria) e em ambientes rurais e urbanos, o trato com distintas alteridades na construção de identidades e na formação para a cidadania (história da África e da cultura afro-brasileira, história indígena, história da América Latina) e a importância social do conhecimento histórico fora dos muros da escola, em sua nova vertente como mercadoria na chamada cultura de massa. Se antes o problema estava na publicização de pesquisas historiográficas, em sua relação com a mediação pedagógica e a cultura escolar, hoje, as discussões da área foram ampliadas para a incorporação de artefatos da cultura contemporânea e para a aprendizagem fora da escola. $\mathrm{O}$ que permanece é a indissociabilidade entre História e ensino.

Além dos novos temas que ocupam o cotidiano dos muitos profissionais comprometidos com a área, o livro também expõe a trajetória da consolidação do ensino de História enquanto campo de pesquisa no Brasil nos últimos quarenta anos, especialmente nos artigos de Maria Carolina Bovério Galzerani e Ernesta Zamboni, Marizete Lucini e Sonia Regina Miranda, que destacam o amadurecimento no uso de referenciais teórico-metodológicos sólidos e pluridimencionais na construção de abordagens próprias e os desafios da aprendizagem temporal, do lugar da memória no saber histórico escolar e da educação das sensibilidades na contemporaneidade. De acordo com as autoras, durante décadas esse campo do conhecimento foi tratado por historiadores, pedagogos e professores do ensino fundamental e médio como uma mera simplificação do conhecimento histórico acadêmico, mas os avanços nas pesquisas e as discussões da área tornaram possível a compreensão do ensino de História como uma área limiar, de passagens fluidas, entre Educação e História, sua ciência de referência, no interior da qual o componente da memória social assume lugar central na configuração de saberes. Mas para que a História possa ser ensinada é preciso mediação pedagógica. Portanto, pensar o ensino de História é ter como referência a dinâmica epistemológica da História e da Educação na inter-relação criadora e singular que deriva da fusão entre esses dois campos.

Assim como aporta os avanços nas discussões da área, o livro revela também alguns dos seus novos desafios, como as interfaces entre memória, história e educação na relação entre ensino de História e história da Educação. Ainda que reconhecidamente as duas áreas tenham objetos distintos, no livro essas entrecruzam-se na abordagem da criança como sujeito histórico, no trato da hegemonia audiovisual na escola e no resgate da história do ensino e da formação de professores de História. Os limites e as barreiras entre as duas áreas não são definidos e a multiplicidade de respostas para a pergunta proposta aumenta. Quem ganha é o leitor, que, com isso, tem acesso a discussões que envolvem o processo educacional como um todo.

Relatos de experiência e memoriais de professores completam a obra, assim como no primeiro livro, com destaque para a republicação da entrevista com o pro- 
fessor e escritor de livros didáticos Rubim Santos Leão de Aquino, falecido em 2013, ano de publicação do livro. A entrevista foi concedida a Selva Guimarães em 1995 e, junto aos demais relatos incorporados, resgata aspectos da formação e das práticas de profissionais de distintas gerações, deixando claro que cada carreira é única, pois cada trajetória é marcada por acontecimentos pessoais e sociais que interferem nas experiências vividas e na própria relação com a História.

Ao final, são comentados os filmes e livros citados pelos autores de modo a auxiliar o leitor na abordagem de tais materiais. Entre as leituras recomendadas estão textos de Marc Ferro, Ernesta Zamboni e Carlos Alberto Vesentini, além de outros livros de Marcos Silva referente ao ensino de História, de autoria própria e organizados em parceria com Selva Guimarães. A lista das produções nacionais e internacionais relacionadas à área é pequena e pouco representativa, mas oferece indícios que permitem localizar a obra e o seu organizador no contexto de pesquisa e de produção de conhecimento no ensino de História.

Em sua trajetória docente e militante, Marcos Silva questionou a proposta educacional da ditadura militar de formar "cidadãos obedientes" e lutou pela reinstituição da História enquanto disciplina autônoma no currículo escolar. Seu trabalho, suas publicações e a organização de obras coletivas como esta traduzem o empenho de muitos pesquisadores ligados à Associação Nacional de História, antes Associação Nacional dos Professores Universitários de História (ANPUH) para interporem-se a descaracterização do ensino de História e a pretensão dos projetos educacionais de homogeneizar os processos de aprendizagem histórica, como bem pontuou Cláudia Sapag Ricci (1999, p. 56), e dos profissionais ligados à Associação Brasileira do Ensino de História (ABEH), criada oficialmente em 2008, que há tempos também têm lutado pela especificidade epistemológica e política do ensino de História como área do conhecimento em diferentes instâncias.

Em linhas gerais, o livro é um convite para pensar o ensino de História como prática política, enraizada no tempo e no espaço, e pautada na construção de identidades e sensibilidades. Comprometido com a dimensão do presente no esforço para acompanhar o mundo da cultura juvenil, a obra traz para os espaços educativos formais e informais a memória em sua dimensão provocadora e problematizadora. Por meio de sua leitura, o ensino de História torna-se mais humano, pessoal e, na medida do possível, vívido.

\section{Referências}

RICCI, Claudia Regina Fonseca Miguel Sapag. Da intenção ao gesto. Quem é quem no ensino de Historia em São Paulo. São Paulo: AnnaBlume, 1999.

SILVA, Marcos Antonio (Org.). Repensando a história. São Paulo: Marco Zero, 1984. . (Org.). História: que ensino é esse? Campinas-SP: Papirus, 2013. 367p. 